\title{
Characterization of Deficient Heme Synthase Activity in Protoporphyria with Cultured Skin Fibroblasts
}

\author{
JOSEPH R. BlOOMER, Howard Hughes Medical Institute Laboratory, \\ Yale University School of Medicine, New Haven, Connecticut 06510
}

A B S T RACT Heme synthase (ferrochelatase) activity, as determined by the chelation of ferrous iron to protoporphyrin or deuteroporphyrin, is reduced to $10-25 \%$ of normal in tissues of patients with protoporphyria. With cultured skin fibroblasts from seven patients with protoporphyria and six normal individuals, the present studies examined the enzymatic defect.

Heme synthase activity in normal and protoporphyria fibroblasts had the same $\mathrm{pH}$ optimum, showed similar inhibition by divalent metals, and had the highest specific activity in the mitochondrial-enriched fraction. The ultrastructural features and other biochemical parameters of mitochondria were normal in protoporphyria cells, excluding a general mitochondrial defect. Measurement of the rate of deuteroheme formation at different concentrations of substrate demonstrated a significant reduction in the apparent $K_{\mathrm{m}}$ for deuteroporphyrin in detergent-treated sonicates of protoporphyria fibroblasts compared to normal (7.5 $\pm 0.9 \mu \mathrm{M}$, mean \pm SEM, vs. $17.4 \pm 1.8$ ), as well as a decrease in the velocity of reaction (mean level was $21 \%$ of normal). Studies with intact cells, in which heme synthase activity was estimated indirectly, also indicated that the apparent $K_{\mathrm{m}}$ for porphyrin substrate was significantly lower in protoporphyria lines.

These data show that heme synthase in protoporphyria fibroblasts has markedly reduced catalytic activity despite an increased affinity for porphyrin substrate. This could be caused by either a change in the enzyme protein, or an alteration of its microenvironment.

\section{INTRODUCTION}

The biochemical abnormalities that characterize the inherited disorders of porphyrin metabolism reflect partial enzymatic defects in the heme biosynthetic

Address reprint requests to Dr. Bloomer at University of Minnesota School of Medicine, Minneapolis, Minn. 55455.

Received for publication 29 March 1979 and in revised form 2 October 1979. pathway. In protoporphyria, protoporphyrin accumulates because of a deficiency in the activity of heme synthase (ferrochelatase), the intramitochondrial enzyme that catalyzes the chelation of ferrous iron to protoporphyrin to form heme. The enzymatic defect has been demonstrated in several tissues from patients with protoporphyria, including liver (1), bone marrow cells $(2,3)$, peripheral blood cells $(4,5)$, and cultured skin fibroblasts $(1,6)$. Deficient heme synthase activity has also been demonstrated in cultured skin fibroblasts from one parent in each of three families in which the children have protoporphyria (7), consistent with the autosomal dominant mode of inheritance that has been postulated for the disease (8).

With the exception of protoporphyria, the residual enzymatic activity in carriers of the genetic defect in the autosomal dominant porphyrias is $\sim 50 \%$ of normal. This is compatible with a structural gene defect in which the mutant allele codes for synthesis of a protein that has minimal activity, although a recent study has suggested there may be a regulatory gene defect in acute intermittent porphyria (9). Residual heme synthase activity in protoporphyria is only $10-25 \%$ of normal, irrespective of the type of tissue studied, raising other possibilities that may explain the enzymatic abnormality: (a) There is a marked reduction in catalytic protein because of either decreased synthesis of normal enzyme (a regulatory gene defect) or accelerated degradation. (b) Protoporphyria cells contain an inhibitor of enzymatic activity, or lack an activator that is present in normal cells. (c) The major portion of heme synthase in protoporphyria cells is structurally different from that in normal cells. This might occur because the enzyme is packaged in the mitochondria in a manner that alters the catalytic site, or because the protein itself is different.

Heme synthase activity in protoporphyria tissue has not been sufficiently compared with that in normal tissue to indicate which of these possibilities is most likely. The present study used cultured skin fibroblasts from normal individuals and patients with 
protoporphyria as a source of heme synthase, and several features of the enzymatic activity were examined.

\section{METHODS}

Fibroblast culture and preparation. Fibroblast cultures were initiated from the skin of six normal individuals and seven patients in whom the diagnosis of protoporphyria was made on the basis of lifelong photosensitivity, a family history of the disease, and elevated erythrocyte protoporphyrin concentrations (range was $272-1,428 \mu \mathrm{g} / 100 \mathrm{ml}$ of cells; normal is $<30$ in this laboratory).

For measuring enzyme activities and other parameters of mitochondrial function, cells in the 5th-20th passages were cultured in $690 \mathrm{~cm}^{2}$ roller bottles (Bellco Glass, Inc., Vineland, N. J.) with Eagle's minimum essential medium supplemented with $1 \%$ nonessential amino acids, $100 \mu \mathrm{g} / \mathrm{ml}$ kanamycin (MEM) ${ }^{1}$, and $10 \%$ fetal calf serum (Flow Laboratories, Inc., Rockville, Md.). The cells were harvested at confluence (7-10 d after plating) into $\mathrm{Ca}$, Mg-free phosphate-buffered saline, $\mathrm{pH} 7.4$, with $0.25 \%$ trypsin (Grand Island Biological Co., Grand Island, N. Y.). After centrifugation, the cell pellet was rinsed with phosphate-buffered saline. The cells were prepared for assay of heme synthase activity by resuspending in $0.25 \mathrm{M}$ sucrose- $0.05 \mathrm{M}$ Tris $\mathrm{Cl}, \mathrm{pH}$ 7.5 , and sonicating three times for $20 \mathrm{~s}$ at a setting of 100 W-S (Heat Systems-Ultrasonics, Inc., Plainview, N. Y.).

Subcellular fractions of the fibroblasts were prepared by hypotonic lysis and differential centrifugation (10). The rinsed cell pellet was suspended in $0.01 \mathrm{M}$ Tris $\mathrm{Cl}, \mathrm{pH} 7.4,0.01 \mathrm{M}$ $\mathrm{KCl}, 0.15 \mathrm{mM} \mathrm{MgCl}_{2}$ at a $1: 10(\mathrm{wt} / \mathrm{vol})$ ratio and allowed to swell for $45 \mathrm{~min}$ at $0^{\circ} \mathrm{C}$ with constant stirring. Sucrose $(2.5 \mathrm{M})$ was then added to give a concentration of $0.25 \mathrm{M}$, and the cell suspension was forced through a 27-gauge needle 20 times to yield a cell homogenate. The homogenate was centrifuged at $700 \mathrm{~g}$ for $10 \mathrm{~min}$ to yield pellet 1 . The supernatant was centrifuged for $10 \mathrm{~min}$ at $10,000 \mathrm{~g}$ to yield pellet 2 . Both pellets and the $10,000 \mathrm{~g}$ supernatant were retained for assay of heme synthase activity. The two pellets were suspended in $0.25 \mathrm{M}$ sucrose-0.05 M Tris $\mathrm{Cl}, \mathrm{pH} 7.5$, and the three fractions were sonicated in the same manner as the whole cell suspension.

Protoporphyrin accumulation was examined in intact cells after culturing the cells to confluence $(5-7 \mathrm{~d})$ in $9.6 \mathrm{~cm}^{2}$ wells of FB-6-TC plates (Linbro Chemical Co., Hamden, Conn.). The confluent monolayer was rinsed with phosphate-buffered saline, and fresh MEM supplemented with $25 \mu \mathrm{M}$ ferrous $\left(\mathrm{Fe}^{++}\right)$sulfate and $\delta$-aminolevulinic acid (ALA, 25-500 $\mu \mathrm{M}$ ) was added. In the absence of supplementation, the concentration of iron in MEM is $<1 \mu \mathrm{M}$. Incubation was carried out at $37^{\circ} \mathrm{C}$ in the dark in a $5 \% \mathrm{CO}_{2}$ and $95 \%$ air atmosphere for $24 \mathrm{~h}$.

Assay of heme synthase activity. Heme synthase activity was measured in sonicated whole cell suspensions and subcellular fractions with minor modifications of the radiochemical assay as described (1). Deuteroporphyrin, the synthetic derivative of protoporphyrin in which the vinyl groups are replaced by hydrogen atoms, was used instead of the natural substrate protoporphyrin because the rate of deuteroheme formation in sonicated fibroblasts is approximately six times that of protoheme, facilitating the assay. Deutero-

${ }^{1}$ Abbreviations used in this paper: ALA, $\delta$-aminolevulinic acid; MEM, Eagle's minimum essential medium supplemented with $1 \%$ nonessential amino acids and $100 \mu \mathrm{g} / \mathrm{ml}$ kanamycin. porphyrin was prepared by dissolving free deuteroporphyrin (Porphyrin Products, Logan, Utah) in 0.6 M Tris base, bringing to $\mathrm{pH} 7.5$ with $\mathrm{HCl}$, filtering, and diluting with distilled water to a final concentration of $1 \mathrm{mM}$ deuteroporphyrin in $0.3 \mathrm{M}$ Tris $\mathrm{Cl}, \mathrm{pH} 7.5$.

${ }^{59} \mathrm{Fe}^{++}$as ferrous sulfate (New England Nuclear, Boston, Mass.) and cold ferrous sulfate were added to $5 \mathrm{~g} / 100 \mathrm{ml}$ ascorbic acid that had been rendered free of $\mathrm{O}_{2}$. The solutions were kept in anaerobic flasks.

The routine assay for heme synthase activity was done anaerobically, employing 1-3 $\mathrm{mg}$ of cell protein, $1-2 \mu \mathrm{Ci}$ ${ }^{59} \mathrm{Fe}^{++}$in $25 \mu \mathrm{M}$ ferrous sulfate, $25 \mu \mathrm{M}$ deuteroporphyrin, $3.5 \mathrm{mM}$ ascorbic acid, $40 \mathrm{mg}$ Tween $20,233 \mathrm{mM}$ Tris $\mathrm{Cl}$, $\mathrm{pH} 7.5$, in a final vol of $4 \mathrm{ml}$. The cell sonicate was incubated with all reagents except $\mathrm{Fe}^{++}$and ${ }^{59} \mathrm{Fe}^{++}$for $15-25 \mathrm{~min}$ on ice, followed by $5 \mathrm{~min}$ at $37^{\circ} \mathrm{C}$ on a shaking water bath, before the reaction was started by the addition of $\mathrm{Fe}^{++}$. Incubation of the tissue with $10 \mathrm{mg} / \mathrm{ml}$ Tween 20 for this period of time effectively solubilized heme synthase, as judged by the fact that activity was recovered quantitatively in the supernatant after centrifugation at $100,000 \mathrm{~g}$ for $30 \mathrm{~min}$, whereas $<1 \%$ of the total activity was recovered in the pellet. In a series of studies with rat liver tissue, Tween 20 was found to be the best detergent for solubilizing heme synthase, in agreement with a previous study by Mazanowska et al. (11).

Nonenzymatic formation of deuteroheme was measured with a tissue blank, prepared by boiling the tissue for $10 \mathrm{~min}$, and a reagent blank in which $0.25 \mathrm{M}$ sucrose-0.05 M Tris $\mathrm{Cl}$, $\mathrm{pH} 7.5$, was substituted for the tissue preparation. The rate of nonenzymatic heme formation did not vary among normal and protoporphyria lines, averaging $22 \pm 1 \mathrm{pmol}$ deuteroheme/ mg protein per $h$, mean $\pm S E M$, for all studies. This was subtracted from the rate of deuteroheme formed in the presence of viable tissue to give the level of enzymatic heme synthase activity.

Kinetic properties of heme synthase were examined by varying the concentration of $\mathrm{Fe}^{++}$from 5 to $25 \mu \mathrm{M}$ while maintaining deuteroporphyrin at $25 \mu \mathrm{M}$, and vice versa. Four to six different concentrations of each substrate were used, and Michaelis-Menten analysis was employed to generate the apparent $K_{\mathrm{m}}$ for both $\mathrm{Fe}^{++}$and deuteroporphyrin (12).

Heme synthase activity was measured indirectly in intact cells in monolayer culture from the difference in the amount of protoporphyrin that accumulated in the absence of added $\mathrm{Fe}^{++}$, vs. that in the presence of $25 \mu \mathrm{M} \mathrm{Fe} e^{++}$, when the medium was supplemented with ALA. Protoporphyrin is the only porphyrin that accumulates in cultured skin fibroblasts when the medium is supplemented with ALA (6). In the absence of added $\mathrm{Fe}^{++}$, protoporphyrin accumulates to a similar degree in both normal and protoporphyria cells because heme synthase is essentially inactive (6). When the medium is supplemented with $\mathrm{Fe}^{++}$, protoporphyrin accumulation is reduced in both cell lines, although much less so in protoporphyria lines, because protoporphyrin is used for heme synthesis (6). The difference in protoporphyrin accumulation thus provides an indirect measurement of heme synthase activity.

Other methods. Succinic dehydrogenase activity was measured by the formation of formazan (13) in sonicates of cells that were suspended in $0.25 \mathrm{M}$ sucrose $-0.05 \mathrm{M}$ Tris Cl, pH 7.5.

Cytochrome oxidase levels were measured by difference spectroscopy in intact cells which were suspended in $0.15 \mathrm{M}$ $\mathrm{KCl}-0.05 \mathrm{M}$ Tris $\mathrm{Cl}, \mathrm{pH} 7.4$ (14). Glycerol (20\%) was added to retard centrifugation of the cells, and the hemoprotein difference spectra were examined with an Amino-Chance split beam spectrophotometer (American Instrument Co., Travenol Laboratories, Silver Spring, Md.) (15). 
Respiratory metabolism of intact cells was determined after suspending the cells in solution containing $0.20 \mathrm{M}$ sucrose, $1 \mathrm{mM}$ EDTA, $5 \mathrm{mM} \mathrm{MgCl}, 10 \mathrm{mM} \mathrm{KCl}, 12 \mathrm{mM}$ phosphate, and $50 \mathrm{mM}$ Tris $\mathrm{Cl}, \mathrm{pH} 7.5$ (16). $1 \mathrm{ml}$ of cell suspension that contained 3.7-6.1 mg of protein was used in each assay. Oxygen uptake was determined polarigraphically with the Clark oxygen electrode (Yellow Springs Instrument Co., Yellow Springs, Ohio). The suspension was incubated at $30^{\circ} \mathrm{C}$ in a glass cuvette fitted with a magnetic stirrer. Additions to the cell suspension were made in volumes of $50 \mu l$ or less.

Ultrastructural features of the cultured fibroblasts were examined with a Zeiss 9S2 electron microscope (Carl Zeiss, Inc., New York). Cells in the 6th-12th passages were cultured to confluence in wells of FB-6-TC plates. They were then fixed and processed as a suspension (17).

Protein concentrations were determined by the method of Lowry et al. (18), with crystalline bovine serum albumin as a standard. The measurements were made on aliquots of the cell suspensions, which had been harvested from roller bottles, and on digests of cells made in the wells of FB-6-TC plates with $0.05 \mathrm{~N} \mathrm{NaOH}$.

Data from normal cell lines were compared with those from protoporphyria lines with the Student's $t$ test.

\section{RESULTS}

Heme synthase activity in sonicates of protoporphyria fibroblasts that had been treated with Tween 20 was $35 \pm 4 \mathrm{pmol}$ deuteroheme/mg protein per $\mathrm{h}$, mean $\pm \mathrm{SEM}$ for seven lines, when assayed on multiple occasions in the presence of $25 \mu \mathrm{M}$ deuteroporphyrin and $25 \mu \mathrm{M} \mathrm{Fe}{ }^{++}$(Fig. 1). This was markedly deficient compared to that in normal lines $(159 \pm 11$, mean \pm SEM for six lines).

Heme synthase activity in detergent-treated sonicates of normal and protoporphyria fibroblasts had the same $\mathrm{pH}$ optimum (7.5-7.7), as determined by measuring the $\mathrm{pH}$ of the complete assay mixture at room temperature. The activity was inhibited by divalent metals (Fig. 2). Most notable was the effect of $25 \mu \mathrm{M}$ copper, which produced nearly complete inhibition.

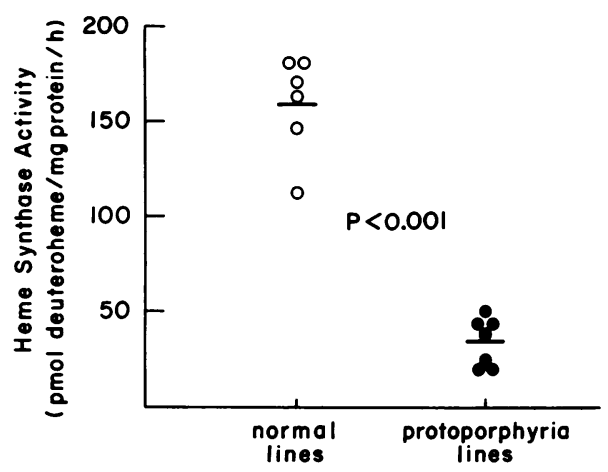

FIgure 1 Heme synthase activity in detergent-treated sonicates of fibroblasts cultured from six normal controls and seven patients with protoporphyria. The value for each line is the average of 2-9 separate studies (total of 32 studies in normal lines and 31 studies in protoporphyria lines). Mean levels for each group are shown by the horizontal bars.

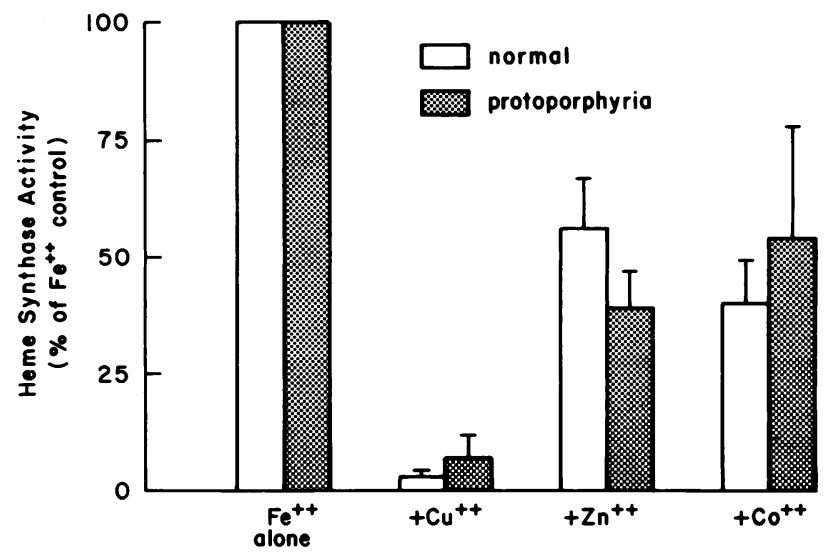

FIGURE 2 Effect of divalent metals on heme synthase activity in detergent-treated sonicates of normal and protoporphyria fibroblasts. The activity measured in the presence of a $25 \mu \mathrm{M}$ concentration of the metal is shown as a percentage of that measured with $25 \mu \mathrm{M} \mathrm{Fe}^{++}$alone (mean $\pm \mathrm{SEM}$ for six normal lines and seven protoporphyria lines). There was no significant difference between normal and protoporphyria lines.

This occurred whether copper was added in the form of copper sulfate or copper chloride.

When harvested fibroblasts were subjected to hypotonic lysis and differential centrifugation, heme synthase had the highest specific activity in the $10,000 \mathrm{~g}$ pellet of both normal and protoporphyria lines (Fig. 3 ). The specific activity of succinic dehydrogenase in this subcellular fraction showed a similar percentage of increase over that in the whole cell sonicate, indicating the fraction was enriched with mitochondria. Of the total heme synthase activity in the cells, $71 \pm 7 \%$ (mean \pm SEM) was recovered in the $10,000 \mathrm{~g}$ pellet of normal lines, vs. $69 \pm 10 \%$ in protoporphyria lines; $94 \pm 2 \%$ was recovered in the combination of pellets from normal lines, vs. $88 \pm 6 \%$ in protoporphyria lines $(P>0.3)$.

Other biochemical parameters of mitochondria were indistinguishable in normal and protoporphyria cells (Table I). The ultrastructural features of protoporphyria fibroblasts also could not be distinguished from those of normal cells. In particular, the mitochondria were well formed, and their inner mitochondrial membranes appeared normal.

Respiratory metabolism was studied in three normal and three protoporphyria lines by adding inhibitors and substrates of the mitochondrial respiratory chain to suspensions of intact cells during the measurement of oxygen consumption (Fig. 4). Rotenone (10 $\mu \mathrm{M})$, which is a potent inhibitor of mitochondrial NADH oxidation, depressed oxygen consumption in both normal and protoporphyria cells. This effect was circumvented by the addition of $10 \mathrm{mM}$ succinate, which transfers electrons to the mitochondrial respiratory chain by way of a different flavoprotein (succinic dehydrogenase). The subsequent addition of 5 

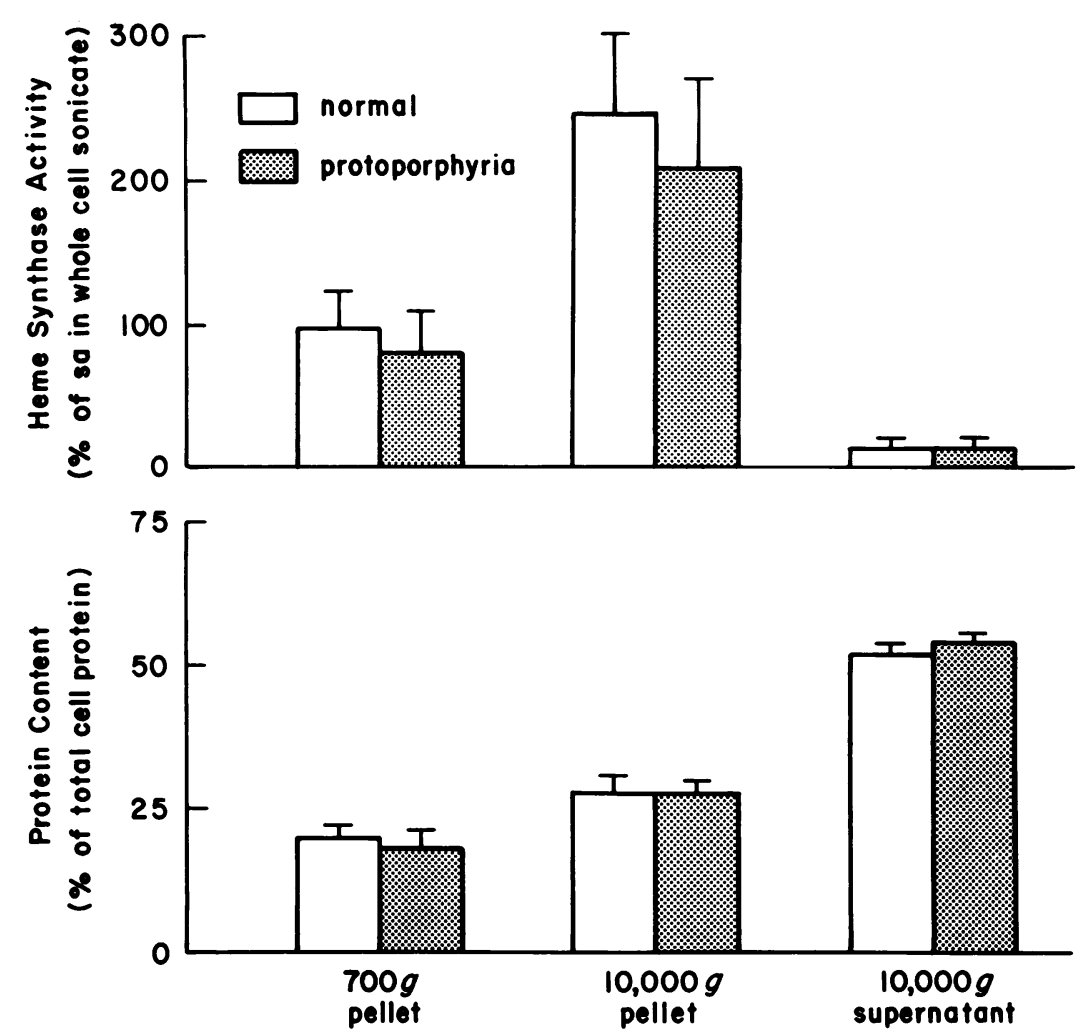

FIGURE 3 Specific activity of heme synthase and protein content in subcellular fractions of fibroblasts as a percentage of the value in the whole cell sonicate (mean \pm SEM). There was no significant difference between normal and protoporphyria lines.

mM malonate, which inhibits succinic dehydrogenase, again depressed oxygen consumption.

Kinetics of heme synthase were examined in cell sonicates that had been treated with Tween 20 by varying the concentration of one of the cosubstrates from 5 to $25 \mu \mathrm{M}$, while maintaining the concentration of the other cosubstrate at $25 \mu \mathrm{M}$. LineweaverBurk plots showed a linear relationship between the reciprocal of the rate of deuteroheme formation and the reciprocal of substrate concentration over this range (Fig. 5). Concentrations higher than $25 \mu \mathrm{M}$ were not

TABLE I

Mitochondrial Parameters of Cultured Skin Fibroblasts

\begin{tabular}{lcc}
\hline & Normal & $\begin{array}{c}\text { Proto- } \\
\text { porphyria }\end{array}$ \\
\hline $\begin{array}{l}\text { Succinic dehydrogenase activity; } \\
\quad n m o l \text { formazan/mg protein } \cdot h\end{array}$ & $6.3 \pm 0.8$ & $5.0 \pm 0.6$ \\
$\begin{array}{l}\text { Cytochrome oxidase concentration, } \\
\quad \text { mmol/mg protein }\end{array}$ & $25.7 \pm 4.8$ & $23.5 \pm 3.9$ \\
$\begin{array}{l}\text { Respiratory activity, natoms } \\
\mathrm{O}_{2} / \mathrm{mg} \text { protein } \cdot \min \end{array}$ & $1.9 \pm 0.2$ & $1.9 \pm 0.5$ \\
\hline
\end{tabular}

All values are mean $\pm S E M$. routinely examined because the nonenzymatic formation of deuteroheme was markedly increased.

Michaelis constants for $\mathrm{Fe}^{++}$and deuteroporphyrin were determined from analysis of the kinetic data (Table II). The apparent $K_{\mathrm{m}}$ for $\mathrm{Fe}^{++}$in protoporphyria lines was not significantly different from that in normal lines. The apparent $K_{\mathrm{m}}$ for deuteroporphyrin was significantly different, however, as the mean value in protoporphyria lines was $43 \%$ of normal. Studies with the $10,000 \mathrm{~g}$ pellet from fibroblasts that had been fractionated by hypotonic lysis and differential centrifugation gave results similar to those with whole cell sonicates.

To provide additional information about the kinetic properties of heme synthase in protoporphyria cells, the enzymatic activity was assayed indirectly in intact cells by comparing the amount of protoporphyrin that accumulated in the presence of $25 \mu \mathrm{M} \mathrm{Fe}^{++}$, vs. that in the absence of $\mathrm{Fe}^{++}$. The difference was taken as the amount of protoporphyrin used in the formation of heme. At low rates of protoporphyrin formation, protoporphyria cells used protoporphyrin in a normal manner (Fig. 6). However, the maximal rate of use was reached at a much lower rate of protoporphyrin formation than in the normal cells. Thus 


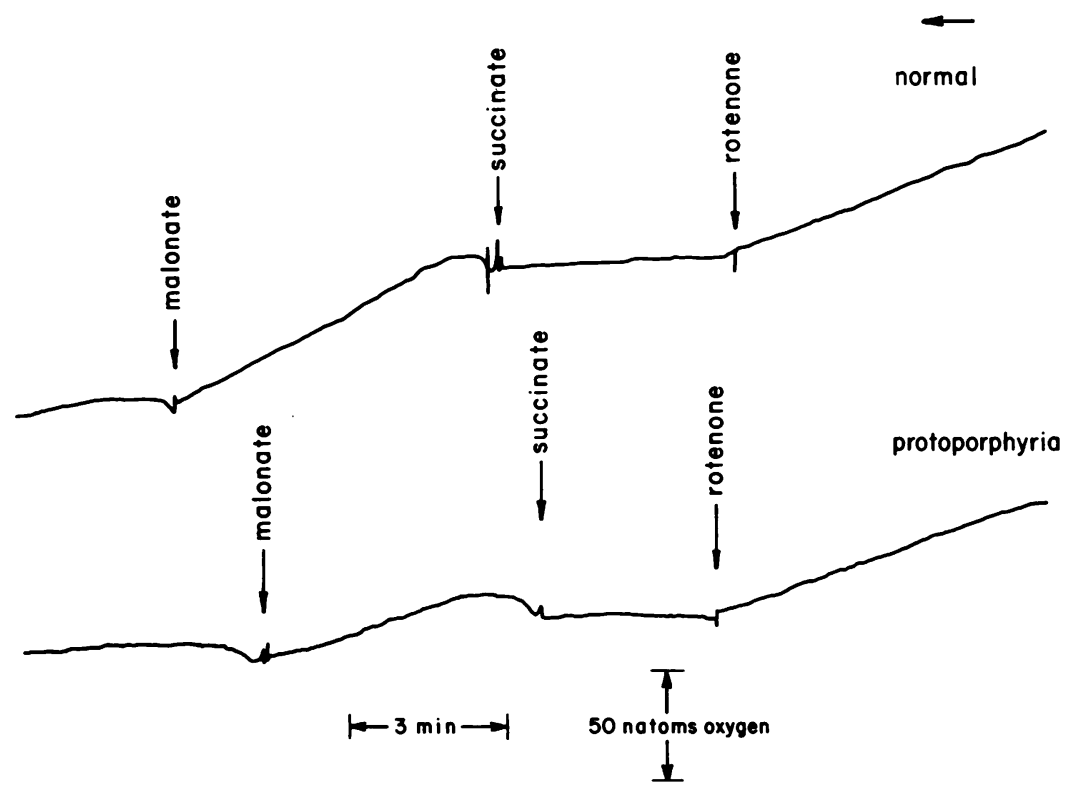

FIGURE 4 Polarigraph tracings on suspensions of intact fibroblasts cultured from a normal individual (5.1 mg cell protein) and a patient with protoporphyria $(6.1 \mathrm{mg}$ cell protein). The slope of the line indicates the rate of oxygen consumption. Sequential additions of rotenone $(10 \mu \mathrm{M})$, succinate $(10 \mathrm{mM})$, and malonate $(5 \mathrm{mM})$ were made to the suspensions at the time indicated by the arrows.

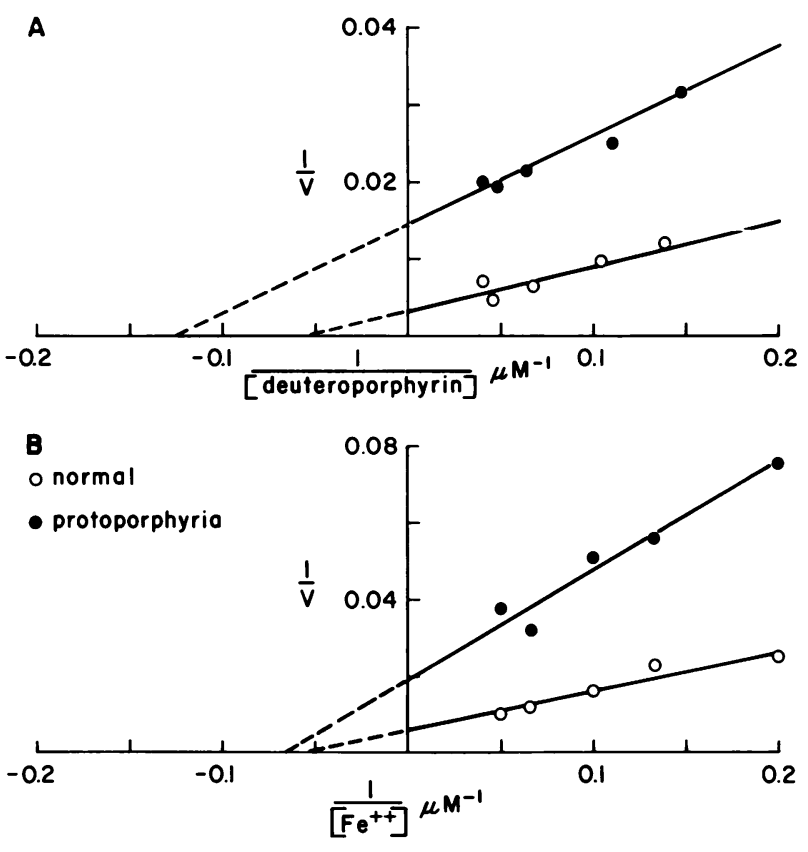

FIGURE 5 Lineweaver-Burk plots of the reciprocal of the rate of deuteroheme formation ( $1 / \mathrm{V}$ in $\mathrm{pmol} / \mathrm{mg}$ protein $\mathrm{h}^{-1}$ ) $\mathrm{vs}$. the reciprocal of the substrate concentration $(1 / S)$. Studies were done with sonicates of fibroblasts that had been treated with $10 \mathrm{mg} / \mathrm{ml}$ Tween 20 . (A) Kinetic analysis for deuteroporphyrin while $\mathrm{Fe}^{++}$was maintained at $25 \mu \mathrm{M}$. (B) Kinetic analysis for $\mathrm{Fe}^{++}$while deuteroporphyrin was maintained at $25 \mu \mathrm{M}$. The apparent $K_{\mathrm{m}}$ were calculated from the abcissa intercepts. the rate of protoporphyrin formation that caused heme production to proceed at a half-maximal rate was significantly lower in protoporphyria cells than in normal cells.

Six studies were done in which combinations of sonicates of normal and protoporphyria fibroblasts were used in the same assay. The observed level of heme synthase activity was less than that predicted if the same catalytically active enzyme were being mixed (Table III). When equal amounts of cellular protein from normal and protoporphyria lines were mixed, the ratio of observed to predicted activity was $0.83 \pm 0.09($ mean \pm SEM $)$ for the six studies $(P<0.05)$.

\section{TABLE II}

Kinetic Analysis of Heme Synthase in Detergent-treated Fibroblast Sonicates

\begin{tabular}{lcc}
\hline & Normal & Protoporphyria \\
\hline No. of lines & 6 & 7 \\
$K_{\mathrm{m}}, \mu M$ & & \\
$\quad \mathrm{Fe}^{++}$ & $8.3 \pm 2.6$ & $12.5 \pm 2.6$ \\
$\quad$ Deuteroporphyrin & $17.4 \pm 1.8$ & $7.5 \pm 0.9^{*}$ \\
$\quad \mathrm{~V}_{\max }, \mathrm{pmol}$ deuteroheme/mg & & \\
$\quad$ protein $\cdot \mathrm{h}$ & $281 \pm 80$ & $58 \pm 13^{*}$ \\
\hline
\end{tabular}

All values are mean \pm SEM.

$* P<0.025$. 


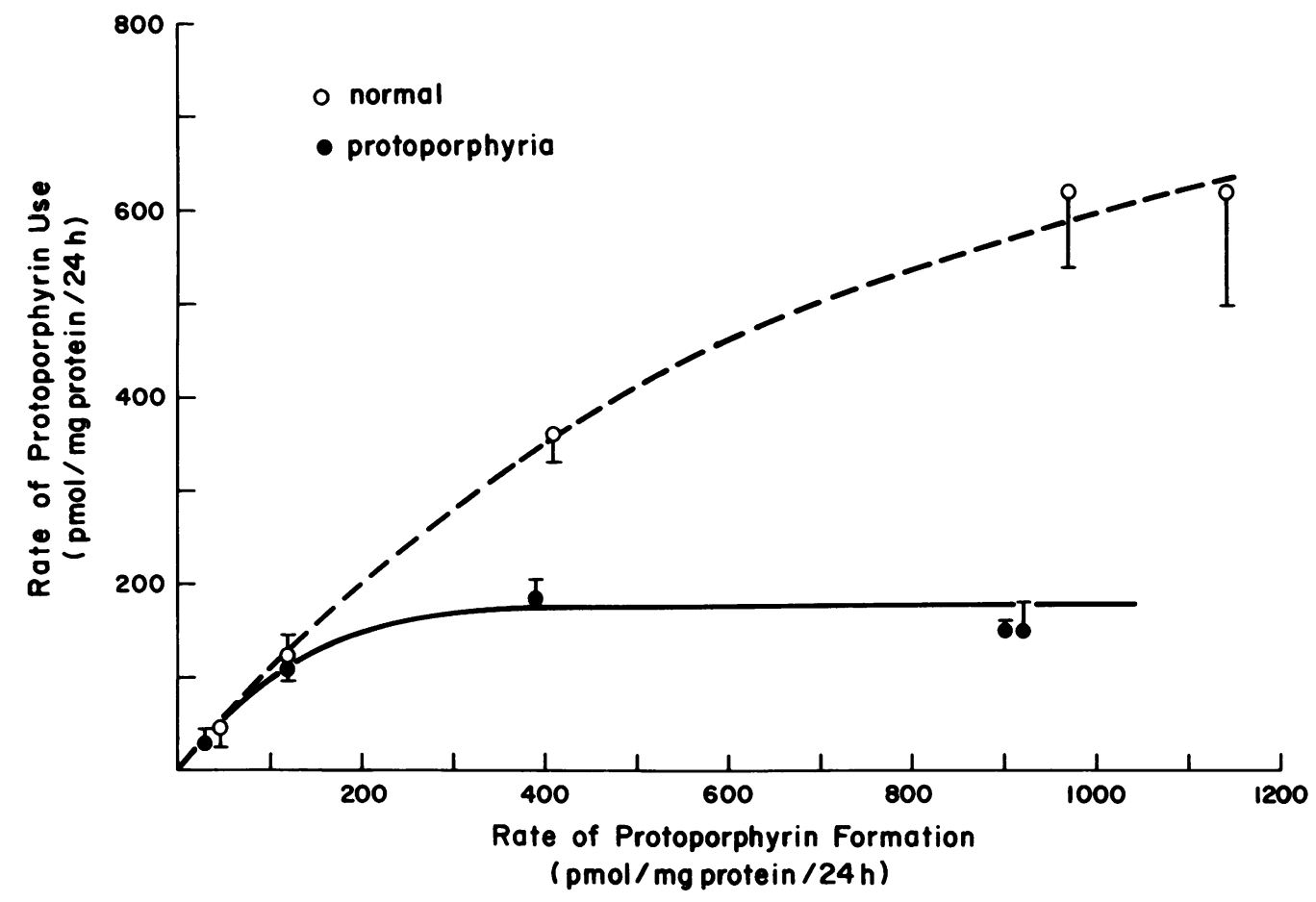

FIGURE 6 Protoporphyrin use by intact normal and protoporphyria cells as a function of the rate of protoporphyrin formation. Protoporphyrin formation was varied by changing the concentration of ALA in the medium (25-500 $\mu \mathrm{M})$. Values are mean \pm SEM for six normal and seven protoporphyria lines.

\section{DISCUSSION}

In this study, cultured skin fibroblasts were used to compare properties of normal heme synthase activity with the defective activity in protoporphyria. Cultured skin fibroblasts have the advantage of being a homogenous population of cells. Bone marrow and peripheral blood contain a heterogenous population of cells with different levels of heme synthase activity (19), making such comparisons difficult.

Heme synthase activity in detergent-treated sonicates of protoporphyria fibroblasts had the same $\mathrm{pH}$ optimum as normal activity and was inhibited similarly by divalent metals. In particular, the addition of

TABLE III

Heme Synthase Activity in Mixtures of Normal and Protoporphyria Fibroblast Sonicates

\begin{tabular}{cccc}
\hline Normal & Protoporphyria & Observed & Predicted \\
\hline & mg protein & & \multicolumn{2}{c}{ pmol deuterohemelh } \\
2.40 & - & 466 & - \\
- & 2.50 & 128 & - \\
- & 1.25 & 64 & - \\
2.40 & 2.50 & 479 & 594 \\
2.40 & 1.25 & 428 & 530 \\
\hline
\end{tabular}

copper nearly abolished the activity (Fig. 2). Previous studies had demonstrated that divalent metals inhibit heme synthase activity in rat liver mitochondria $(20,21)$. The simplest explanation is that divalent metals compete with ferrous iron for chelation to porphyrin. Depending on the method of tissue preparation and assay, copper had either an inhibitory or stimulatory effect, however $(20,21)$. Copper restored the effectiveness of glutathione as a reducing agent in promoting heme synthesis in rat liver mitochondria that had been solubilized with detergent and dialyzed (21). It stimulated heme synthase that had been partially purified from bacteria (22).

Heme synthase activity was localized to the same subcellular fraction of normal and protoporphyria fibroblasts. Because the enzyme is known to be attached to the inner mitochondrial membrane of mammalian cells $(23,24)$, it was expected that the highest specific activity would be in the mitochondrialenriched fraction from normal cells (Fig. 3). Nevertheless, it could not be assumed that this would be the case in protoporphyria cells.

Deficient heme synthase activity in protoporphyria cells could be caused by the presence of an inhibitor, or the absence of an activator. The mixing studies excluded the possibility that protoporphyria cells lack an activator that facilitates heme synthase ac- 
tivity (Table III). In this situation, the activity measured in mixtures of normal and protoporphyria sonicates should have exceeded the sum of the individual activities, whereas it was always less. Although the result is compatible with the presence of an inhibitor in protoporphyria cells, the kinetic data favor another possibility. They suggest that enzymes with different catalytic properties were being mixed. In this situation, the activity that resulted was apparently not additive.

Kinetic studies confirmed that the catalytic activity of heme synthase in protoporphyria cells was markedly reduced. In addition, they indicated that the apparent Michaelis constant for porphyrin substrate was different (Table II). Of particular note, the apparent $K_{m}$ for deuteroporphyrin was reduced, not increased as might be expected. In the rapid equilibrium model of enzyme kinetics, the constant $K_{\mathrm{m}}$ is equivalent to the dissociation constant for the enzyme-substrate complex, and the rate-limiting step is the conversion of the enzymesubstrate complex to product and free enzyme (12). Thus the kinetic data suggest that heme synthase in protoporphyria sonicates has an increased affinity for porphyrin cosubstrate, but there is a decreased rate of conversion of the enzyme-porphyrin complex to heme and free enzyme. This is not without precedent, inasmuch as several variants of glucose-6-phosphate dehydrogenase have been described in which reduced erythrocyte activity is accompanied by a reduced $K_{\mathrm{m}}$ for glucose-6-phosphate (25).

At low rates of protoporphyrin formation, protoporphyrin was used in a normal manner by intact protoporphyrin cells (Fig. 6). However, as the rate of protoporphyrin formation increased, its rate of use became saturated much sooner than in normal cells. Although the data cannot be strictly analyzed by Michaelis-Menten analysis, they support the premise that the catalytic activity of heme synthase is markedly reduced in protoporphyria cells despite an increased affinity for porphyrin.

Because genetic disorders are generally believed to occur as a result of alterations in the amounts or structures of specific proteins, one interpretation of these data is that the enzyme protein responsible for heme synthase activity is structurally changed in protoporphyria cells. However, the data do not exclude the possibility that the microenvironment of the enzyme protein is altered. Even though determinations of the Michaelis constant for porphyrin were made with detergent-treated sonicates, it is conceivable that lipids may have remained attached to the enzyme protein. Indeed, several studies have indicated that heme synthase activity may require specific lipids (26-28), and it is conceivable that the lipid environment of the enzyme is abnormal in the mitochondria of protoporphyria cells.
Further clarification of the enzymatic abnormality in protoporphyria requires purification of heme synthase so that kinetic properties of the unconstrained protein can be examined in the presence and absence of specific lipids, and so that the amount of immunologically reactive protein can be quantitated. This should provide definitive evidence as to how the enzyme in tissues of patients with this dominant disease is different than that in normal tissues.

\section{ACKNOWLEDGMENTS}

I would like to thank Ms. Andi Bartczak, Janice Munroe, and Rose Allen for technical assistance. Dr. Patricia Latham examined the ultrastructural features of the cultured fibroblasts.

This study was supported by Research grant AM-19009 from the National Institutes of Health.

\section{REFERENCES}

1. Bonkowsky, H. L., J. R. Bloomer, P. S. Ebert, and M. J. Mahoney. 1975. Heme synthetase deficiency in human protoporphyria. Demonstration of the defect in liver and cultured skin fibroblasts. J. Clin. Invest. 56: 1139-1148.

2. Bottomley, S. S., M. Tanaka, and M. A. Everett. 1975. Diminished erythroid ferrochelatase activity in protoporphyria. J. Lab. Clin. Med. 86: 126-131.

3. Becker, D. M., J. D. Viljoen, J. Katz, and S. Kramer. 1976. Reduced ferrochelatase activity: a defect common to porphyria variegata and protoporphyria. $\mathrm{Br} . \mathrm{J}$. Haematol. 36: 171-179.

4. deGoeij, A. F. P. M., K. Christianse, and I. van Steveninck. 1975. Decreased haem synthetase activity in blood cells of patients with erythropoietic protoporphyria. Eur. J. Clin. Invest. 5: 397-400.

5. Brodie, M. J., M. R. Moore, G. G. Thompson, A. Goldberg, and G. Holti. 1977. Haem biosynthesis in peripheral blood in erythropoietic protoporphyria. Clin. Exp. Dermatol. 2: 351-388.

6. Bloomer, J. R., D. A. Brenner, and M. J. Mahoney. 1977. Study of factors causing excess protoporphyrin accumulation in cultured skin fibroblasts from patients with protoporphyria. J. Clin. Invest. 60: 1354-1361.

7. Bloomer, J. R., H. L. Bonkowsky, P. S. Ebert, and M. J. Mahoney. 1976. Inheritance in protoporphyria: comparison of heme synthetase activity in skin fibroblasts with clinical features. Lancet. II: 226-228.

8. Haeger-Aronsen, B. 1963. Erythropoietic protoporphyria. A new type of inborn error of metabolism. Am. J. Med. 35: 450-454.

9. Sassa, S., G. L. Zalar, and A. Kappas. 1978. Studies in porphyria. VII. Induction of uroporphyrinogen-I synthase and expression of the gene defect of acute intermittent porphyria in mitogen-stimulated human lymphocytes. J. Clin. Invest. 61: 499-508.

10. Mahoney, M. J., A. C. Hart, V. D. Steen, and L. E. Rosenberg. 1975. Methylmalonicacidemia: biochemical heterogeneity in defects of 5'-deoxyadenosylcocobalamin synthesis. Proc. Natl. Acad. Sci. U. S. A. 72: 2799-2803.

11. Mazanowska, A., A. M. Dancewicz, T. Malinowska, and E. Kowalski. 1969. Chelation of iron and zinc by protoporphyrin catalyzed by mitochondrial preparations. Eur. J. Biochem. 7: 583-587.

12. Ferdinand, W. 1976. The enzyme molecule. John Wiley \& Sons Ltd., Sussex, England. 26-36. 
13. Shephard, E. H., and G. Hübscher, 1969. Phosphatide biosynthesis in mitochondrial subfractions of rat liver. Biochem. J. 113: 429-440.

14. Brenner, D. A., and J. R. Bloomer. 1977. Heme content of normal and porphyric cultured skin fibroblasts. Biochem. Genet. 15: 1061-1070.

15. Chance, B. A. 1957. Techniques for the assay of respiratory enzymes. In Methods of Enzymology. S. P. Colowick and N. D. Kaplan, editors. Academic Press, Inc., New York. Vol. IV. 273-329.

16. Warshaw, J. B., and M. L. Terry. 1970. Cellular energy metabolism during fetal development. II. Fatty acid oxidation by the developing heart. J. Cell. Biol. 44: 354-360.

17. Steinman, R. M., and Z. A. Cohn. 1972. The interaction of soluble horseradish peroxidase with mouse peritoneal macrophages in vitro. J. Cell. Biol. 55: 186-204.

18. Lowry, O. H., N. J. Rosebrough, A. L. Farr, and R. J. Randall. 1951. Protein measurements with the Folin phenol reagent. J. Biol. Chem. 193: 265-275.

19. Langelaan, D. E., M. S. Losowsky, and C. Toothill. 1970. Haem synthetase activity of human blood cells. Clin. Chim. Acta. 27: 453-459.

20. Labbe, R. F., and N. Hubbard. 1961. Metal specificity of the iron-protoporphyrin chelating enzyme. Biochim. Biophys. Acta. 52: 130-135.

21. Wagner, G. S., M. L. Dinamarca, and T. R. Tephly.
1975. Studies on ferrochelatase activity: role in regulation of hepatic heme biosynthesis. In Porphyrins in Human Diseases. M. Doss, editor. S. Karger AG, Basel. $111-122$.

22. Dailey, H. A. 1977. Purification and characterization of the membrane-bound ferrochelatase from spirillium itersonii. J. Bacteriol. 132: 302-307.

23. Jones, M. S., and O. T. G. Jones. 1969. The structural organization of haem synthesis in rat liver mitochondria. Biochem. J. 113: 507-514.

24. McKay, R., R. Druyan, G. S. Getz, and M. Rabinowitz. 1969. Intramitochondrial localization of $\delta$-aminolaevulate synthetase and ferrochelatase in rat liver. Biochem. J. 114: 455-461.

25. Harris, H. 1975. The Principles of Human Biochemical Genetics. Elsevier North Holland Biomedical Press, Amsterdam, Nethe̊rlands. 162-174.

26. Mazanowska, A. M., A. Neuberger, and G. H. Tait. 1966. Effect of lipids and organic solvents on the enzymic formation of zinc protoporphyrin and haem. Biochem. J. 98: 117-127.

27. Sawada, H., M. Takeshita, Y. Sugita, and Y. Yaneyama 1969. Effect of lipid on protoheme ferro-lyase. Biochim. Biophys. Acta. 178: 145-155.

28. Simpson, D. M., and R. Poulson. 1977. Effects of lipids on the activity of ferrochelatase. Biochim. Biophys. Acta. 482: 461-469. 